\title{
Pelatihan Penyusunan KTSP PAUD 2013 Untuk Kepala Taman Kanak- Kanak di Bekasi Utara
}

\author{
Khusniyati Masykuroh*1, Amelia Vinayastri ${ }^{2}$ \\ 1,2 Universitas Muhammadiyah Prof. Dr. HAMKA \\ ${ }^{3}$ Program Studi PG PAUD, Fakultas Keguruan dan Ilmu Kependidikan, Universitas Muhammadiyah Prof. \\ Dr. HAMKA \\ *e-mail: khusniyati.masykuroh@uhamka.ac.id ${ }^{1}$, amelia.vinayastri@uhamka.ac.id ${ }^{2}$
}

\begin{abstract}
The Head of Kindergarten (TK) is expected to be able to develop an operational curriculum in an Education Unit Level Curriculum (KTSP) which has the uniqueness because it is the institution's reference in organizing programs, implementing various services in the institution, implementing the learning process, and evaluating learning outcomes in accordance with the characteristics PAUD unit. Based on preliminary observations obtained information that most of the kindergartens in North Bekasi sub-district do not have KTSP PAUD 2013 yet. This shows that these institutions do not have a curriculum development direction yet, the Kindergarten Head has not carried out their functions in managing the institution especially in leading the development team curriculum. Therefore the service team organized the 2013 PAUD KTSP Preparation Training for the Head of Kindergarten in North Bekasi District, which was attended by 30 Head of Kindergarten, Deputy Head of Kindergarten, and PKG PAUD management. The results of the training are an increasing of trainees knowledge on the importance of curriculum development and an increasing of trainees skills developing the KTSP.
\end{abstract}

Key words : KTSP, knowledge, skill

\begin{abstract}
Abstrak
Kepala Taman Kanak-kanak (TK) diharapkan mampu mengembangan kurikulum operasional dalam Kurikulum Tingkat Satuan Pendidikan (KTSP) yang mempunyai kekhasan karena merupakan acuan lembaga dalam menyelenggarakan program, melaksanakan berbagai layanan di lembaga, dan melaksanakan proses pembelajaran, dan evaluasi hasil belajar sesuai dengan karakteristik satuan PAUD. Berdasarkan observasi awal diperoleh informasi bahwa sebagian besar Taman Kanak-kanak di kecamatan Bekasi Utara belum memiliki KTSP PAUD 2013. Hal ini menunjukkan bahwa lembaga-lembaga tersebut belum mempunyai arah pengembangan kurikulum, artinya Kepala TK belum menjalankan fungsinya dalam mengelola lembaga khususnya dalam memimpin tim pengembang kurikulum. Oleh karena itu tim pengabdi menyelenggarakan Pelatihan Penyusunan KTSP PAUD 2013 untuk Kepala TK di Kecamatan Bekasi Utara yang diikuti oleh 30 Kepala TK, Wakil Kepala TK, dan pengurus PKG PAUD. Hasil pelatihan menunjukkan peningkatan pengetahuan para peserta pelatihan terhadap pentingnya pengembangan kurikulum dan peningkatan keterampilan para peserta pelatihan dalam menyusun KTSP.
\end{abstract}

Kata kunci: KTSP, pengetahuan, keterampilan

\section{PENDAHULUAN}

Kurikulum merupakan bagian terpenting dari sistem pendidikan Nasional, yang keberadaannya telah ada sejak awal keberadaan pendidikan Nasional (Ali, 2013) Kurikulum mengalami proses pengembangan penyempurnaan guna meningkatan kualitas Pendidikan Indonesia (Rahelly, 2018). Kurikulum memiliki posisi strategis karena secara umum kurikulum merupakan deskripsi dari visi, misi, dan tujuan pendidikan, sekaligus memposisikan kurikulum sebagai sentral muatan-muatan nilai yang akan ditransformasikan kepada peserta didik (Bahri, 2017). Menurut Undang-Undang Republik Indonesia Nomer 20 Tahun 2003 tentang Sistem Pendidikan Nasional, Kurikulum adalah seperangkat rencana dan pengaturan mengenai tujuan, isi, dan bahan pelajaran serta cara yang digunakan sebagai pedoman penyelenggaraan kegiatan pembelajaran untuk mencapai tujuan pendidikan nasional. Kurikulum menekankan pada apa yang dapat dilakukan siswa dengan pengetahuan, bukan pada unit apa pengetahuan yang mereka miliki, adalah inti dari keterampilan abad ke-21 (Silvia, 2009). 
Kurikulum 2013 Pendidikan Anak Usia Dini bertujuan untuk mendorong berkembangnya potensi anak agar memiliki kesiapan untuk menempuh pendidikan selanjutnya. Memaknai kesiapan menempuh pendidikan selanjutnya mencakup kemampuan-kemampuan yang diperlukan untuk menunjang keberhasilan anak dalam mengikuti pendidikan di jenjang lebih tinggi. Kemampuan yang dimaksud terdiri atas kemampuan sikap, kemampuan pengetahuan, dan kemampuan keterampilan. Kurikulum 2013 Pendidikan Anak Usia Dini merupakan bagian yang tak terpisahkan dari kebijakan pengembangan kurikulum pendidikan nasional, dan memiliki kesinambungan dengan kurikulum 2013 pada jenjang pendidikan di atasnya. Kurikulum 2013 PAUD menetapkan struktur kurikulum yang sama untuk semua jenjang pendidikan tanpa menghilangkan kekhasan program masing-masing. Kebijakan tersebut didasarkan pada pemahaman bahwa pembentukan sumber daya manusia yang andal harus dimulai sejak usia dini secara berkelanjutan hingga jenjang pendidikan tertinggi dalam satu sistem pendidikan.

Pada tahun 2014 Kementerian Pendidikan dan Kebudayaan menerbitkan Peraturan Menteri Pendidikan dan Kebudayaan Nomor 137 tentang Standar Pendidikan Anak Usia Dini dan Peraturan Menteri Pendidikan dan Kebudayaan Nomor 146 tahun 2014 tentang Kurikulum 2013 Pendidikan Anak Usia Dini. Standar PAUD terdiri atas delapan standar, yaitu; (1) Standar Tingkat Pencapaian Perkembangan Anak (STPPA), (2) Standar Isi, (3) Standar Proses, (4) Standar Penilaian, (5) Standar Pendidik dan Kependidikan, (6) Standar Pengelolaan, (7) Standar Sarana dan Prasarana, dan (8) Standar Pembiayaan. Kurikulum 2013 PAUD mengembangkan kemampuan sikap, pengetahuan, dan keterampilan sebagai satu komponen yang saling terkait dan tidak dapat terpisahkan. Setiap subkomponen tersebut memiliki fokus arahan dan bila disatukan membangun kompetensi lulusan PAUD yang memiliki kesiapan mengikuti pendidikan lebih lanjut. Pembentukan sikap diarahkan membangun kemampuan fungsi eksekutif yang ditenggarai dengan (1) kemampuan memori kerja otak dalam mengatur kemampunan mempertahankan dan mengelola informasi berbeda dalam waktu singkat. (2) fleksibilitas mental yang membantu mempertahankan respons dari tuntutan yang berbeda dalam waktu singkat. (3) kontrol diri dalam hal menentuan prioritas and menolak tindakan/respons yang menarik. Pembentukan pengetahuan konseptual untuk membangun kemampuan kreatif dengan menggunakan cara berpikir tinggi (high order thinking). Pengembangan keterampilan berpikir runut prosedural yang diterapkan baik melalui pembiasaan (habituasi) maupun pendekatan saintifik yang dalam proses pembelajaran guna dapat membangun kebebasan imajinasi, berpikir kritis, dan kreativitas anak (Rahelly, 2018).

Setiap lembaga PAUD diharapkan mengembangan kurikulum operasional dalam bentuk Kurikulum Tingkat Satuan Pendidikan (KTSP). KTSP untuk PAUD adalah kurikulum operasional yang dikembangkan dan dilaksanakan sesuai dengan karakteristik satuan PAUD, seperti keadaan lingkungan, pendidik, peserta didik, sarana prasarana, biaya, dan nilainilai yang mendasari, serta program yang akan dilakukan oleh satuan PAUD (Nugraha, Nurmiati, Wahyuningsih, \& Wujiati, 2018). KTSP setiap lembaga mempunyai kekhasan karena merupakan acuan lembaga dalam menyelenggarakan program, melaksanakan berbagai layanan di lembaga, dan melaksanakan proses pembelajaran dan evaluasi hasil belajar sesuai dengan karakteristik satuan PAUD (Chandrawaty \& Masykuroh, 2020). Untuk dapat mengembangkan KTSP, Tim Pengembang Kurikulum Tingkat Satuan Pendidikan perlu memahami ide Kurikulum 2013 PAUD, karena tampa memahami ide yang termuat didalamnya maka KTSP yang dikembangkan akan berbeda dan bukan merupakan kesinambungan dari ide Kurikulum 2013 PAUD (Prihantini, 2018). Kepala Taman Kanak-kanak (TK) dan tim pengembang kurikulum mempunya peran strategis dalam pengembangan kurikulum di lembaga PAUD masing-masing. KTSP tiap lembaga menunjukkan kekhasan dan menunjukkan keunggulan masing-masing sekolah.

Berdasarkan observasi awal diperoleh informasi bahwa sebagian besar Taman Kanakkanak di kecamatan Bekasi Utara belum memiliki Kurikulum Tingkat Satuan Pendidikan (KTSP) berdasarkan Kurikulum PAUD 2013. Hal ini menunjukkan bahwa lembaga-lembaga tersebut belum mempunyai arah pengembangan kurikulum, artinya Kepala TK belum menjalankan fungsinya dalam mengelola lembaga khususnya dalam memimpin tim pengembang kurikulum. Padahal kurikulum adalah jantungnya proses Pendidikan dan menunjukkan kualitas layanan 
lembaga PAUD. Dalam observasi juga ditemukan informasi bahwa banyak kepala TK yang belum memahami Kurikulum PAUD 2013, belum memiliki dokumen peraturan dan pedoman tentang Kurikulum PAUD 2013, serta belum mempunyai keterampilan penyusunan Kurikulum Tingkat Satuan Pendidikan.

Penelitian Muhlasin pada tahun 2016 yang berjudul Meningkatkan Kompetensi Kepala Sekolah Dalam Menyusun Ktsp Melalui Pembinaan Terprogram menunjukkan bahwa pembinaan terprogram dapat meningkatkan kompetensi kepala sekolah dasar dalam menyusun KTSP, ditunjukkan dengan Kepala sekolah dapat menjawab secara runtut pertanyaan mengenai KTSP, dapat menjelaskan prosedur dan isi KTSP (Muhlasin, 2016). Penelitian berikutnya dilakukan oleh R. Mekar Ismayani dan Diena San Fauziya pada tahun 2019 menunjukkan bahwa :1) Pelatihan kurikulum 2013 sangat membantu para guru dalam menghadapi dan mengimplementasikan berbagai macam kebijakan; 2) Pelatihan kurikulum 2013 menciptakan kemampuan dan keterampilan dalam menyusun RPP bagi guru; 3) Pelatihan kurikulum 2013 memberikan bekal tatacara membangun pembelajaran yang berpusat pada keaktifan siswa (Ismayani \& Fauziya, 2019)

\section{METODE}

Kegiatan pengabdian ini menggunakan metode partisipatoris yang melibatkan peserta sebagai sumber belajar dan peserta juga praktek langsung sehingga peserta tidak hanya memahami teori tetapi juga praktek penyusunan Kurikulum Tingkat Satuan Pendidikan PAUD 2013. Pelatihan penyusunan KTSP PAUD 2013 yang diikuti oleh para Kepala Taman Kanakkanak (TK) Kecamatan Bekasi Utara bertujuan untuk meningkatkan pemahaman para Kepala TK akan Kurikulum PAUD 2013 dan meningkatkan keterampilan dalam menyusun Kurikulum Tingkat Satuan Pendidikan di lembaga masing-masing. dilaksanakan bekerjasama dengan Pusat Kerja Gugus (PKG) PAUD Kecamatan Bekasi Utara. Pelatihan diikuti oleh 30 orang Kepala TK, Wakil Kepala TK, dan pengurus PKG PAUD Kecamatan Bekasi Utara. Pelatihan terbagi menjadi tiga sesi yang terdiri dari sesi pertama dengan materi Peran Kepala TK Dalam Menyiapkan Kurikulum Menghadapi Revolusi Industri 4.0., sesi kedua membahas materi Kurikulum PAUD 2013, dan sesi ketiga peserta pelatihan praktek menyusun Kurikulum Tingkat Satuan Pendidikan sesuai dengan lembaga masing-masing dan dilanjutkan dengan membuat rencana tindak lanjut. Untuk mengetahui tingkat keberhasilan pelatihan, dilakukan pre-test dan post-test kepada para peserta pelatihan.

\section{HASIL DAN PEMBAHASAN}

Pengabdian masyarakat Pelatihan Penyusunan KTSP PAUD 2013 dilaksanakan selama dua hari pada bulan Maret 2019 oleh tim dosen pengabdi dan melibatkan dua orang mahasiwa. Pelatihan diawali dengan materi Peran Kepala TK Dalam Menyiapkan Kurikulum Menghadapi Revolusi Industri 4.0. Pada sesi ini kepala TK diberikan wawasan mengenai : 1) tantangan Revolusi Industri 4.0 termasuk dalam bidang pendidikan; 2) Keterampilan yang dibutuhkan dalam Abad 21; 3) Peran kepala sekolah dalam memimpin sekolah; 4) Menentukan Visi Misi Sekolah; 6) Mengetahui kekuatan dan kelemahan sekolah; 7) Kepala Sekolah Sebagai Agen Perubahan; 8) Pentingnya Membuat Pedoman; 9) Pengembangan Kurikulum Sekolah dalam Menghadapi Revolusi Industri 4.0. 


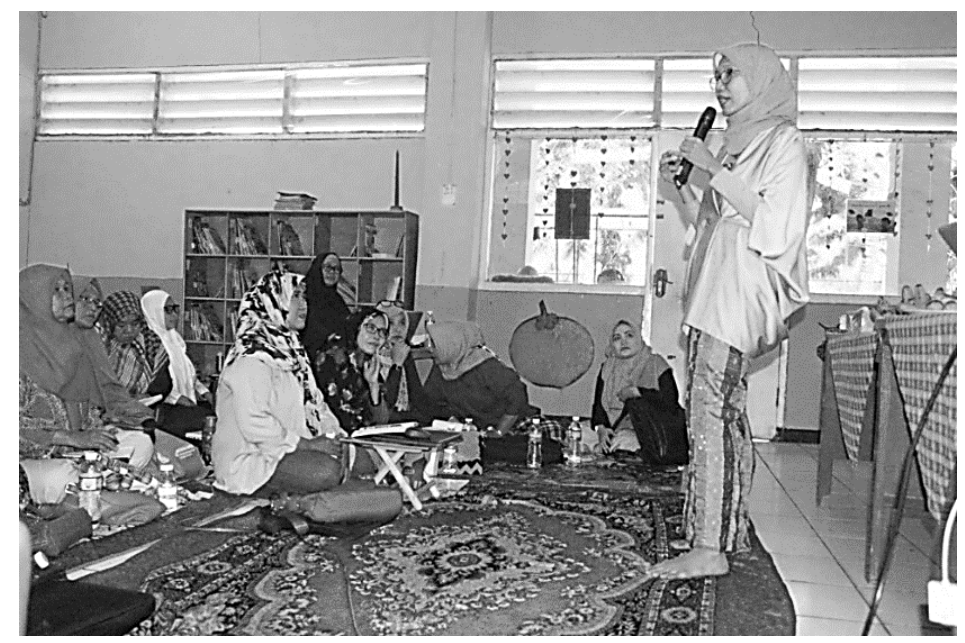

Gambar 1. Penyampaian Materi Pelatihan

Pelatihan berlangsung interaktif dengan strategi paparan, game and ice breaking, tanya jawab, dan penugasan kepada peserta pelatihan. Pada materi pertama, peserta sangat antusias dan perhatian mengikuti materi tentang tantangan Revolusi Industri 4.0 bagi pendidikan dan peran penting kepala sekolah dalam menyusun kurikulum yang mampu menghadapi tantangan tersebut. Para peserta berdiskusi dan menyampaikan kendala-kendala yang mereka hadapi di sekolah terkait dengan perkembangan teknologi saat ini. Peserta pelatihan mendapatkan wawasan tentang Revolusi Industri 4.0 yang telah menunjukkan bahwa globalisasi tidak hanya fenomena yang berdampak pada bidang teknologi saja, namun telah mendisrupsi berbagai bidang lain seperti sosial, hukum, dan ekonomi (Sasmito, Wijayanto, Ode, \& Zulfiqar, 2020). Sehingga penting bagi para Kepala TK untuk melakukan pengembangan kurikulum dengan mengedepankan kompetensi abad 21 untuk meminimalkan bahaya disrupsi.

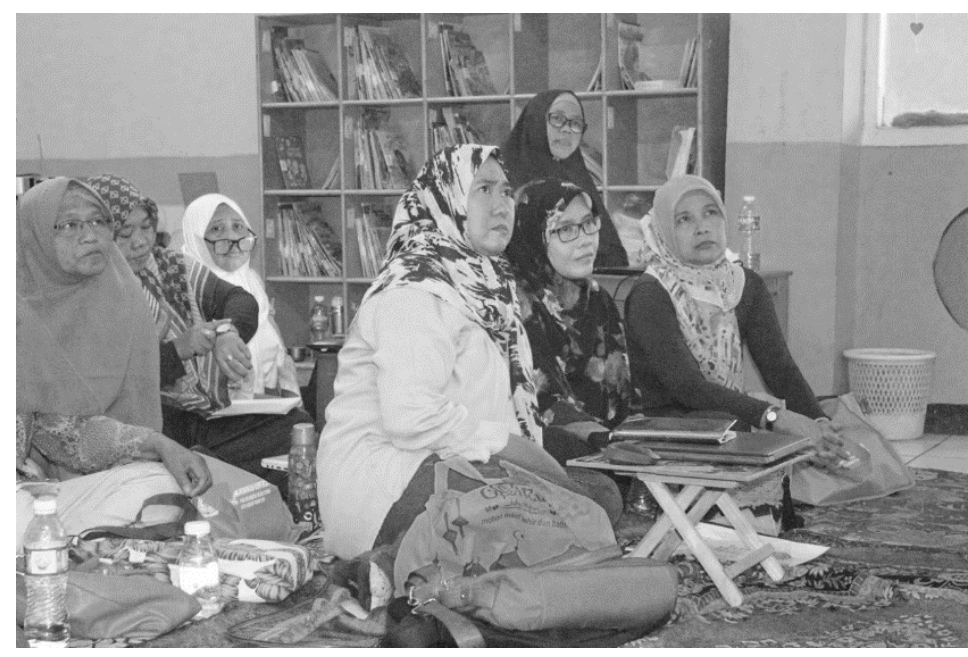

Gambar 2. Peserta mengikuti pelatihan dengan penuh perhatian.

Pada sesi kedua, pengabdi membahas materi mengenai Kurikulum PAUD 2013. Pada sesi ini, para kepala TK mendapatkan wawasan tentang : 1)Perkembangan Kurikulum di Indonesia; 2) Arah Pembangunan PAUD 2011-2045; 3) Mengapa PAUD memerlukan kurikulum yang berkualitas; 4) Mengapa Kurikulum Perlu Dikelola; 5) Kurikulum Tingkat Satuan Pendidikan (KTSP); 6) Prinsip-prinsip KTSP; 7) Komponen KTSP, dan 8) Langkah-langkah menyusun KTSP. Pelatihan berlangsung hangat dan penuh semangat. Peserta diberikan kesempatan untuk 
bertanya untuk mendapatkan respon dan masukan dari pengabdi maupun dari peserta yang lain. Peserta diberi kesempatan untuk melakukan evaluasi terhadap proses penyusunan dan pelaksanaan kurikulum di lembaga PAUD masing-masing.

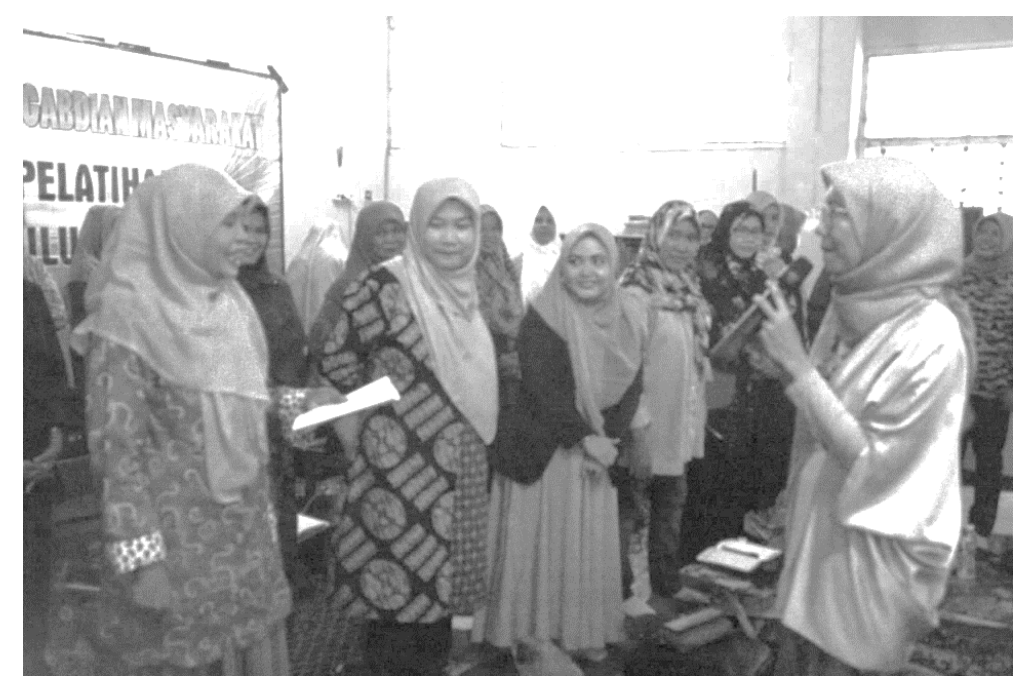

Gambar 3. Peserta terlibat aktif selama pelatihan

Sesi ketiga dari pelatihan adalah praktek membuat Kurikulum Tingkat Satuan Pendidikan. Setiap Kepala atau Wakil Ketua TK telah membawa bahan serta dokumen dari sekolah masing-masing, kemudian mencoba menyusun Dokumen 1 dan Dokumen KTSP. Dokumen 1 terdiri dari : 1) Visi, misi, dan tujuan satuan pendidikan; 2) Muatan pembelajaran yang mengacu pada Kompetensi Inti dan Kompetensi Dasar; 3) Pengaturan Beban Belajar; 4) Struktur Kurikulum, dan 5) Kalender Pendidikan. Sedangkan pada Dokumen 2, para peserta praktek menyusun Program Semester, Rencana Pelaksanaan Pembelajaran Mingguan (RPPM), dan Rencana Pembelajaran Harian (RPPH).

Pengabdi mendorong para peserta pelatihan untuk merancang pembelajaran yang mengusung pendekatan saintifik karena melalui pendekatan ini anak diberi kesempatan yang seluas-luasnya untuk terlibat langsung dalam pembelajaran, memuaskan rasa ingin tahu, mencari jawaban sendiri, dan membangun pengetahuannya sendiri (membelajarkan diri sendiri), sehingga mendorong terbentuknya daya pikir tingkat tinggi (high order thinking skill). Aktivitas-aktivitas yang dilakukan dalam pembelajaran hendaknya dapat memberikan kesempatan seluas-luasnya kepada siswa untuk melakukan aktivitas tingkat tinggi sehingga kemampuan tingkat tinggi dapat dioptimalkan (Nuris, Suparti, \& Sulastri, 2018). Pendekatan saintifik merupakan proses ilmiah dalam pembelajaran yang diyakini sebagai jembatan emas perkembangan dan pengembangan sikap, keterampilan, dan pengetahuan peserta didik. Pendekatan Saintifik juga dapat diartikan sebagai pendekatan pembelajaran yang memberikan kesempatan kepada anak untuk mendapat pengalaman belajar melalui mengamati, menanya, mengumpulkan informasi, menalar, dan mengkomunikasikan (Nurani, 2015). Dalam pendekatan atau proses kerja yang memenuhi kriteria ilmiah, para ilmuwan lebih mengedepankan pelararan induktif (inductive reasoning) ketimbang penalaran deduktif (deductive reasoning)(Waseso, 2018).

Melalui pendekatan saintifik, anak-anak dapat mengintegrasikan bahasa, literasi, matematika, dan pengembangan sains (Gerde, Schachter, \& Wasik, 2013). Prinsip-prinsip pendekatan saintifik adalah : 1) Pembelajaran berpusat pada siswa; 2) Pembelajaran membentuk students self concept; 3) Pembelajaran terhindar dari verbalisme; 4) Pembelajaran memberikan kesempatan pada siswa untuk mengasimilasi dan mengakomodasi konsep; 5) Pembelajaran mendorong terjadinya peningkatan kemampuan berfikir siswa; 6)Pembelajaran meningkatkan motivasi belajar siswa dan motivasi mengajar guru; 7) Memberikan kesempatan kepada siswa untuk melatih kemampuan dalam komunikasi; 8) Adanya kegiatan konstruksi pengetahuan oleh siswa 
(Daryanto, 2014). Pendekatan saintifik diharapkan dapat mengembangkan sikap jujur, teliti, disiplin, taat aturan, kerja keras kemampuan menerapkan prosedur dan kemampuan berpikir induktif serta deduktif dalam menyimpulkan (Vinayastri, Masykuroh, Fitriani, \& Anugerahwaty, 2019). Pendekatan saintifik memberi pengalaman belajar yang bermakna dengan mendorong kemampuananak dalam mengamati, menanya, mengumpulkan informasi, menalar, dan mengomunikasikan, mendorong anak untuk mencari sumber-sumber informasi untuk menjawab keingintahuannya, dan membangun anak memiliki kemampunan berpikir kritis dalam memecahkan masalah.

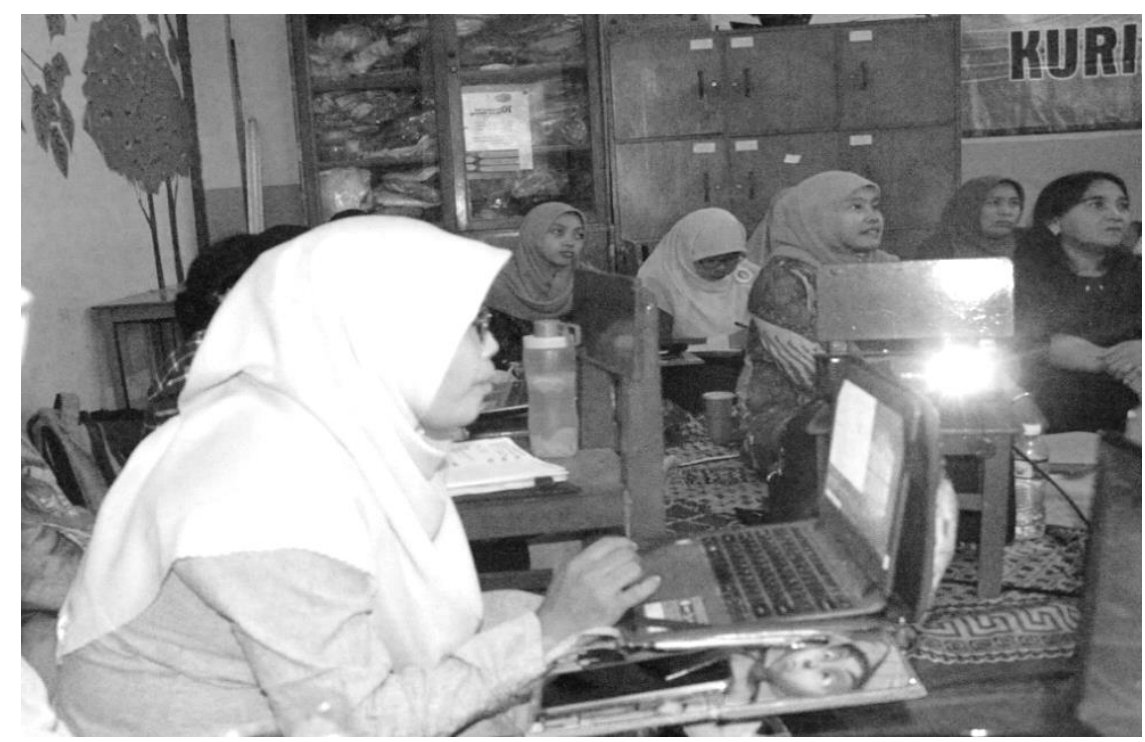

Gambar 4. Peserta Praktik Menyusun KTSP

Dalam sesi akhir pelatihan, peserta melakukan post-test dan memberikan testimoni terhadap pelaksanaan pelatihan. Salah satu peserta menyampaikan bahwa sebagai Kepala TK sangat perlu mengembangkan kurikulum di lembaganya karena dalam menghadapi tantangan revolusi industri, lembaga PAUD harus kreatif dan mampu menunjukkan ciri khasnya, serta tidak tertinggal dengan kemajuan teknologi. Kepala TK perlu menyusun KTSP secara dinamis mengikuti perkembangan jaman, tuntutan dan kebutuhan masyarakat karena kurikulum akan mengalami perubahan dan pergeseran seiring dengan dinamika perubahan sosial yang disebabkan berbagai faktor. Kurikulum harus bersifat fleksibel dan merespon dengan cepat dinamika perubahan sosial supaya mampu menghasilkan output pendidikan yang dinamis dan up to date.

\section{KESIMPULAN}

Secara keseluruhan Pelatihan Penyusunan Kurikulum Tingkat Satuan Pendidikan PAUD 2013 untuk para Kepala TK di Kecamatan Bekasi Utara berjalan dengan lancar dan berhasil dalam upaya memberikan penguatan kepada Kepala Sekolah mengembangkan Kurikulum di lembaga masing-masing melalui penyusunan Kurikulum Tingkat Satuan Pendidikan (KTSP) PAUD 2013 untuk menghadapi tantangan Revolusi Industri 4.0. Hasil wawancara dan post-test yang dilakukan setelah pelatihan menunjukkan peningkatan pengetahuan para peserta pelatihan terhadap pentingnya pengembangan kurikulum pada satuan pendidikan dalam menghadapi Revolusi Industri 4.0 Hal ini ditunjukkan dengan peningkatan nilai post test dibandingkan dengan nilai pre-test. Selain itu hasil pelatihan menunjukkan meningkatnya keterampilan para peserta pelatihan dalam menyusun Kurikulum Tingkat Satuan Pendidikan di masing-masing lembaga.

Kegiatan pelatihan yang dilaksanakan selama dua hari hanya mampu memberikan pendampingan kepada peserta mengenai pentingnya peran Kepala Sekolah dalam menyusun KTSP di lembaga masing-masing, namun belum bisa memberikan pendampingan dalam pelaksanaan. Oleh karena itu tim pengabdi bekerjasama dengan Pusat Kerja Gugus PAUD 
Kecamatan Bekasi Utara dalam proses pendampingan pelaksanaan dan pada kegiatan pengabdian selanjutnya bisa melakukan evaluasi pelaksanaan kurikulum sehingga pelaksanaan KTSP bisa lebih terukur, mengetahui kendala yang dihadapi saat pelaksanaan, serta bisa memberikan masukan untuk perbaikan.

\section{UCAPAN TERIMA KASIH}

Pengabdi mengucapkan terima kasih kepada pihak-pihak yang telah memberi dukungan finansial maupun non-finansial dalam pengabdian ini yaitu :

1. Rektor Universitas Muhammadiyah Prof. DR. HAMKA.

2. Ketua Lembaga Penelitian dan Pengabdian Masyarakat UHAMKA.

3. Dekan Fakultas Keguruaan dan Ilmu Kependidikan UHAMKA.

4. Penilik PAUD Kecamatan Bekasi Utara, Kota Bekasi.

5. Ketua Pusat Kerja Gugus PAUD Kecamatan Bekasi Utara, Kota Bekasi.

\section{DAFTAR PUSTAKA}

Ali, M. (2013). Implementasi Kurikulum Pendidikan Nasional 2013. Jurnal Pedagogi.

Bahri, S. (2017). Pengembangan Kurikulum Dasar dan Tujuannya. Jurnal Ilmiah Islam Futura. https://doi.org/10.22373/jiif.v11i1.61

Chandrawaty, \& Masykuroh, K. (2020). Persepsi Mahasiswa Terhadap Model Project Based Learning Dalam Penyusunan Kurikulum Tingkat Satuan Pendidikan. Early Childhood : Jurnal Pendidikan, 4(1), 35-43.

Gerde, H. K., Schachter, R. E., \& Wasik, B. A. (2013). Using the Scientific Method to Guide Learning: An Integrated Approach to Early Childhood Curriculum. Early Childhood Education Journal, 41(5), 315-323. https://doi.org/10.1007/s10643-013-0579-4

Ismayani, R. M., \& Fauziya, D. S. (2019). Pelatihan Kurikulum 2013 di Tingkat Sekolah dasar. Jurnal Pengabdian Kepada Masyarakat IKIP SIliwangi, 02(01), 11-16.

Muhlasin. (2016). Meningkatkan Kompetensi Kepala Sekolah Dalam Menyusun Ktsp Melalui Pembinaan Terprogram. Sosialita, 10(1), 81-92.

Nugraha, A., Nurmiati, Wahyuningsih, S., \& Wujiati. (2018). Penyusunan Kurikulum Tingkat Satuan Pendidikan (E. Yulaelawati \& K. Restuningsih, eds.). Direktorat Pembinaan Pendidikan Anak Usia Dini, Direktorat Jenderal PAUD Dikmas, Kemdikbud.

Nurani, Y. (2015). Implementasi Kurikulum 2013 PAUD. Jakarta: Yayasan Yefebo.

Nuris, D. M., Suparti, \& Sulastri. (2018). Pelatihan penyusunan perangkat pembelajaran berbasis tik bagi guru akuntansi smk 1,2,3. Dinamisia - Jurnal Pengabdian Kepada Masyarakat, 2(2), 256-260.

Prihantini, P. (2018). Kajian Ide Kurikulum 2012 PAUD dan Implikasinya dalam Pengembangan KTSP. Cakrawala Dini: Jurnal Pendidikan Anak Usia Dini. https://doi.org/10.17509/CD.V8I2.10535

Rahelly, Y. (2018). Implementasi Kurikulum 2013 Pendidikan Anak Usia Dini (PAUD) di Sumatera Selatan. jpud JPUD - Jurnal Pendidikan Usia Dini, 12(2), 381-390.

Sasmito, G. W., Wijayanto, S., Ode, L., \& Zulfiqar, M. (2020). Studi Pengenalan Internet of Things Bagi Guru dan Siswa SMK Bina Nusa Slawi Sebagai Wawasan Salah Satu Ciri Revolusi Industri 4 . 0. Dinamisia : Jurnal Pengabdian Kepada Masyarakat, 4(1), 186-194.

Silvia, E. (2009). Measuring Skills for 21st-Century Learning. Phi Delta Kappan.

Vinayastri, A., Masykuroh, K., Fitriani, E., \& Anugerahwaty, R. (2019). Analisis Pengaruh Pendekatan Saintifik Dan Pemberian Reward Terhadap Perkembangan Anak Usia Dini. JPP PAUD FKIP UNTIRTA, 6(1), 11-20.

Waseso, H. P. (2018). Kurikulum 2013 Dalam Perspektif Teori Pembelajaran Konstruktivis. TaLim : Jurnal Pendidikan Islam, 1(1), 59-72. 